\title{
プロラクチン産生脳下垂体 microadenoma
}

\section{一 I 診断㧍よび内分泌学的考察—}

\section{佐藤 修・田辺 純嘉・土田 博美 \\ Prolactin-secreting Pituitary Microadenomas}

\author{
-I Diagnosis and Endocrinological Evaluation-
}

Osamu Sato, Sumryoshi Tanabe and Hiromi Tsuchita

Department of Neurosurgery, Sapporo Medical College, Sapporo 060

\begin{abstract}
Summary
The authors report 12 cases of prolactin-secreting pituitary microadenomas and discuss the neuroradiological diagnosis and endocrinological evaluations.

The patients were all females between 28 and 38 years of age. Eleven cases sustained amenorrhea or oligomenorrhea with galactorrhea and one case sustained only amenorrhea. Four cases had already experienced delivery and the symptoms had continued since the last delivery in three cases. Transsphenoidal surgery confirmed the size of the tumor within $10 \mathrm{~mm}$ in diametcr.

Plain radiograms of the sella turcica showed a normal sellar area and sellar volume but indicated two cases with a doublc floor of the sclla and one case with localized ballooning along the anteroinferior portion of the sella. Hypocycloidal tomograms at $2 \mathrm{~mm}$ intervals in the lateral view showed localized 'expansion' with 'cortical thinning' along the sellar floor in all cases. The findings were located at the anteroinferior portion of the sella in nine cases and at the inferior or posteroinfcrior portion in three cases. Hypocycloidal tomograms in the AP view, however, showed abnormalities of the sellar floor in only four cases.

Conventional CT scans with contrast could not definitely delineate microadenomas. The wide width 'bone window CT scan" showed localized expansion of the central portion of the sella in two cases, diffuse expansion of the sella in one case and localized lateral expansion of the sella in one case.

Subtraction magnification angiograms were normal and pncumoencephalotomograms did not demonstrate suprasellar extension of the tumors.

Results of the endocrinological examinations were compared with those of prolactin-secreting pituitary macroadenomas.

The basal serum PRL levels tended to be higher in macroadenomas but no clear separation could be made between the two groups. Retarded response of serum PRL to TRH was observed in a single case of microadenoma but not in cases of macroadenomas. Diurnal changes of serum PRL were absent both in microadenomas and macroadenomas. The L-dopa suppression effect on serum PRL was observed in nine out of 11 microadenomas and four out of five macroadenomas. The Bromocriptine suppression effect on serum PRL was observed in about half of both groups.

The L-dopa stimulation effect on serum HGH was normal in six out of ten microadenomas and one out of five macroadenomas. The insulin tolerance test on serum $\mathrm{HGH}$ was normal in four out of five microadenomas and subnormal in both macroadenomas. The HGH reserve was subnormal in five out of 12 microadenomas and
\end{abstract}

\section{札幌医科大学脂神経外科}

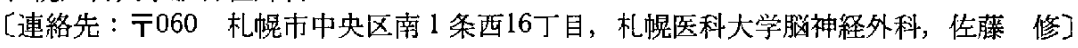

1980年 2 月 15 日 受稿 
four out of five macroadenomas.

The LH and FSH reserves for LH-RH were impaired in three and one case respectively out of 11 microadenomas and were greatly impaired (three out of six and two out of fve respectively) in macroadenoma cases.

The TSH and ACTH reserves werc rarely impaired both in microadenomas and macroadenomas.

In conclusion, hypocycloidal tomograms in the lateral view proved very valuable in the detcction of microadenomas. In the endocrinological examinations, the PRL and HGH reserves were impaired but the TSH, LH, FSH and ACTH reserves were only slightly impaired in microadenomas. In macroadenomas, however, the LH and FSH reserves were also impaired.

Key words : functioning pituitary adenoma, microadenoma, prolactin, neuroradiology, endocrinology

\section{Iはじめに}

Radioimmunoassay によるホルモン測定の進歩, hypocycloidal tomographyによるトルコ鞍の検冞法の進步 により，その臨床症候の特徴と相まって，ホルモン産生 脳下垂体腺腫の診断は容易となり，特に初期の microadenoma の時期に発見される例が増えてきた。我々注， 無月経，乳汁漏出を主訴とし，血中プロラクチン (PRL) 值が简值を示す microadenoma について，特に神経放射 線学的診断, 内分泌学的所見について検討老行ったので 報告する.

\section{I 症例}

1978年10月から1979年11月まで札幌医科大学脳神経外 科で手術が行われた PRL 産生脳下垂体 microadenoma は12例である。症例は寸べて女性で，年令は28〜38才 (平均32才) で女る。監床症候として，無月経と乳汁漏 出を伴5\&010例，月経減少と乳汁漏出在伴 5 もの 1 例，無月程のみのもの1例である。無月経の持続期間は 8 力月 8 年 (平均 5 年 2 力月) で，11例中 10 例加 2 年 以上の長期にわたっている．出産の既往のあるもの4例 厄，5ち3例㤕産後加ら症候が持続している，視力， 視野障害が办られたものは1例もない，腺腫の直径は10 $\mathrm{mm}$ 以下で，トルコ鞍面秸 ${ }^{12}$, トルコ鞍容積 ${ }^{83}$ はともに 正常範囲に市った。

\section{III検查方法}

\section{1. 神経放射線学的検查法}

トルコ鞍単純撮影， $2 \mathrm{~mm}$ 間隔 hypocycloidal tomography, CT scan (横断像, 削頭断像), bone window CT $\operatorname{scan}^{252}$, subtraction 拉大連続血管撮影，気腷断層撮 影安行った。

\section{2. 内分泌学的検查法}

(1) PRL 分泌機能

血清 PRL について，(1)日内変動測定 $(8.00 \mathrm{a} . \mathrm{m}$ ， 12.00 a.m., 4.00 p.m., 8.00 p.m., 12.00 p.m.,
$4.00 \mathrm{a} . \mathrm{m})$, (2) TRH 試験 (500 $\mu \mathrm{g}$ 静注), (3) $\mathrm{L}-$ dopa 試駼 (500 mg 内服) 抒び Bromocriptine 試験 (2.5 mg内服) 学行った。

(2) $\mathrm{HGH}$ 分淡機能

血清 HGH について, (1) E内変動測定, (2) ITT (insulin $0.1 \mathrm{U} / \mathrm{kg}$ 静注), (3) $\mathrm{L}$-dopa 試験を行った.

(3) TSH 分泌機能

血清 TSH についてTRH 試験を行い，さらに血清 $T_{9}$ resin 摂取率および $\mathrm{T}_{3}, \mathrm{~T}_{4}$ 值老測定した。

(4) LH, FSH 分泌機能

血清 LH, FSH について，LH-RH 試験 (100 $\mu \mathrm{g}$ 静注) を行った。

(5) ACTH 分泌機能

(1)血清 cortisol の日内変動測定，(2)血清 ACTH 飞 ついてITT，(3)尿中 17-OHCS，17-KS 測定Lt. 血清11-OHCS を测定した例もある。

\section{VV 結 果}

\section{1. 神経放射線学的検查所見}

トルコ鞍単純撮影側面像で異常所胃を呈したものは 3

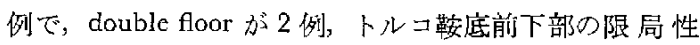
ballooning が1 例にみられた（Fig. 1)。これに反し， hypocycloidal tomography ${ }^{26)}$ では，側面像で全例にトル 二鞍庭の限局性 “expansion” と “cortical thinning” みられた。これらの変化の大部分はトルコ鞍底の前下部 にみられ，下部拉よび後下部にみられたのは 3 例に過ぎ ない(Fig. 2). Hypocycloidal tomography の正面像で 異常がみられたのは4 例に過ぎない。

CT scan で contrast enhancement デトルコ鞍内に限局 性の高吸收城がみられたのは2例で，いずれも手術所見 での腺腫の大きさと位置が一致しなかったので, 正常媨 下垂体と考えられた（Fig，3)。

Bone window $\mathrm{CT}^{25}$ で卜ルコ鞍に異常がみられたもの は 4 例で，トルコ鞍中央拡大型 2 例，トルコ鞍全体扡大 型 1 例，トルコ唼内限局性側方括大型 1 例であった。

Subtraction 拉大連続血管撮影で異常所見がみられた 


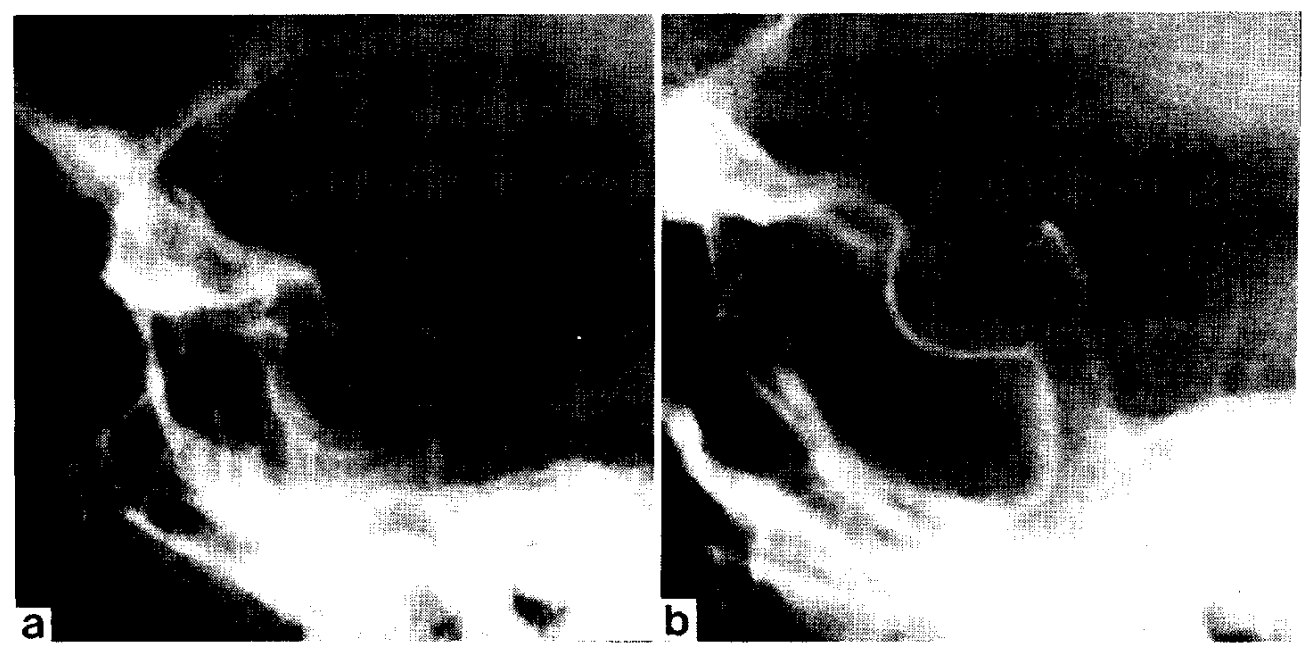

Fig. 1 Plain radiograms of the sella turcica showed a double floor of the sella turcica (a) in 2 cases and localized ballooning along the anteroinferior margin of the sella turcica (b) in one case.
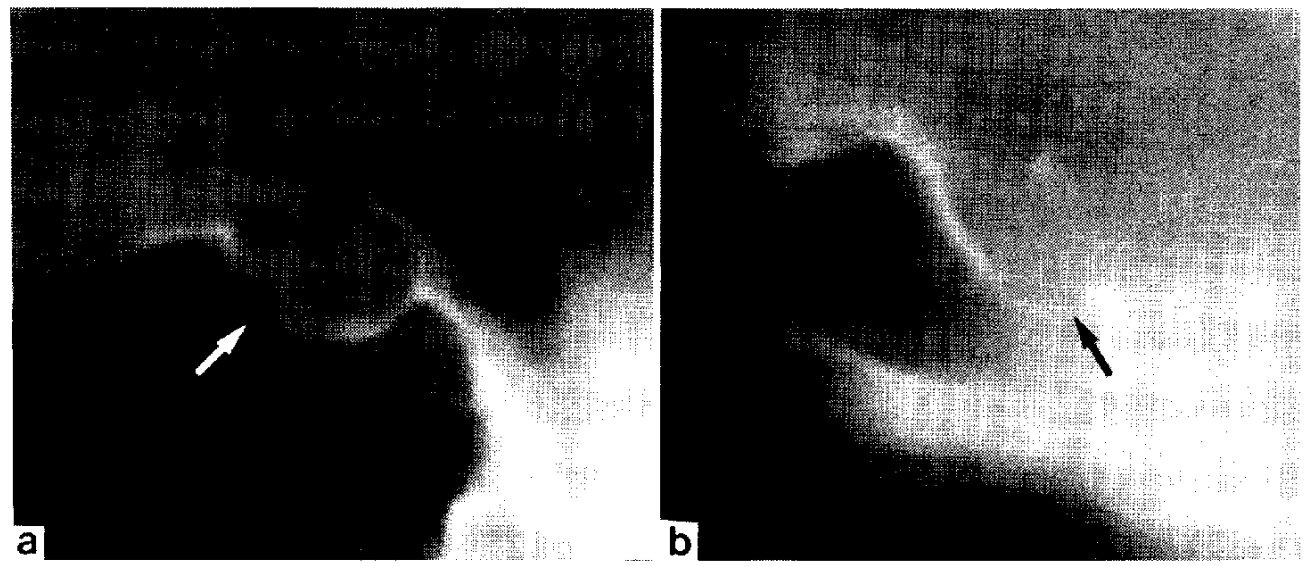

Fig. 2 Hypocycloidal tomograms in the lateral view showed localized 'expansion' with 'cortical thinning' along the anteroinferior margin of the sclla turcica (a) in 9 cases and along the inferior or posteroinferior margin (b) in 3 cases.

例は 1 例むなかった。

気譄断層撮影で鞍隔膜の形を㩰索すると水平型10例， 上方凹型 2 例で，上方凹型は 1 例むなかった。

以上の所見加ら， microadenoma の神経放射線学的診 断には, hypocycloidal tomography の側面像がもっとも 有㺫であった。

\section{2. 内分泌学的検查所見}

立な検查結果を Table 1 に示す. 腺腫の直径がl1 mm 以上で，トルコ桉の桩大，破壊が明らかで，高 PRL 血 症在伴 5 PRL 産生腷下垂体 macroadenoma 10 例経 験しているが，このうち比較的内分泌学的検查が行えた 6 例を対比して Table 1 に示寸. なお，腺腫が視床下部
に伸展L，二次的に高 PRL 血症を呈したと考えられる 例除外した。

\section{(1) PRL 分泌機能}

各種目荷試験における血清 PRL 基礎值（正常：30 $\mathrm{ng} / \mathrm{m} l$ 以下) の平均值が $200 \mathrm{ng} / \mathrm{m} l$ 越えるものは, microadenoma では 12例中 3 例 $(25 \%)$ で, macroadenoma 010 例中 7 例 $(70 \%)$ に比し，明らかに少ない

(Fig.4). した仿って，腺腫の大きいはど，血清 PRL 㽰は高い傾向にあるといえる。しかし，血清 PRL 值だ けで両者を鑑別することはできなかった．

TRH 試験で仗, microadenoma で基礎值が400 ng/ml を越えた 2 例を除き，10例中わずか1例に60分後に遅延 


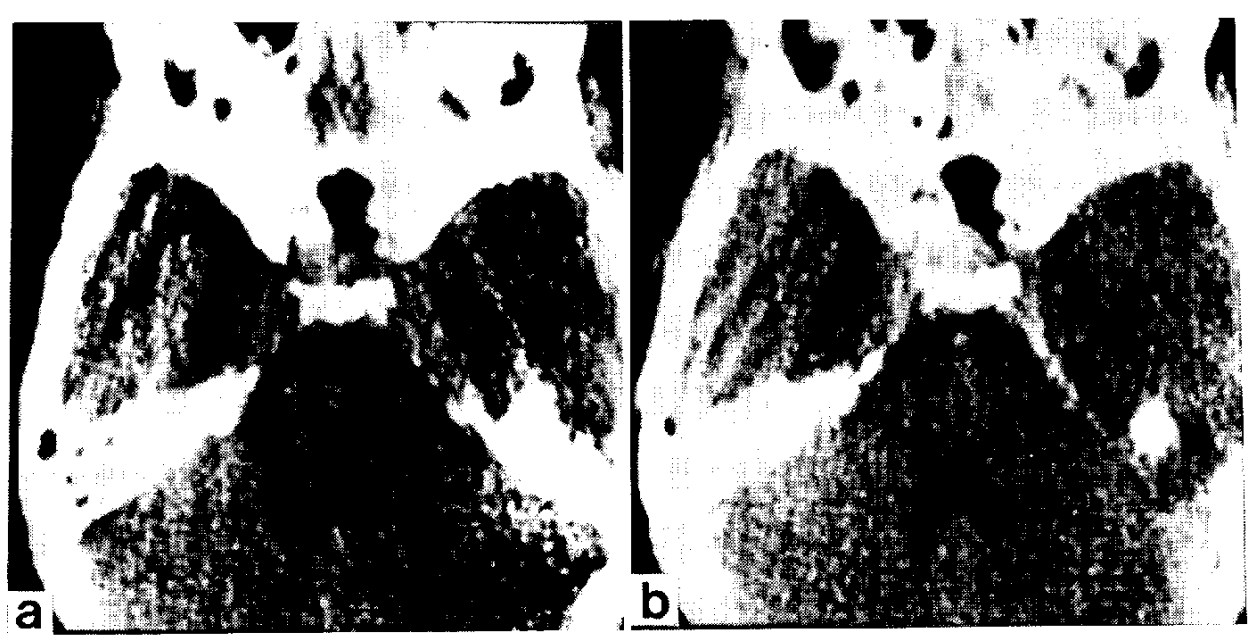

Fig. 3 Conventional CT scans showed a slightly hyperdense nodular area (a) with enhancement effect (b) within the sclla turcica in 2 cases but it was considered to be a normal pituitary gland according to the location of the tumor which was confirmed by surgery.

Table 1 Results of endocrinological examinations in 12 cases of PRL-secreting pituitary microadenoma comparcd with 6 cascs of macroadenoma.

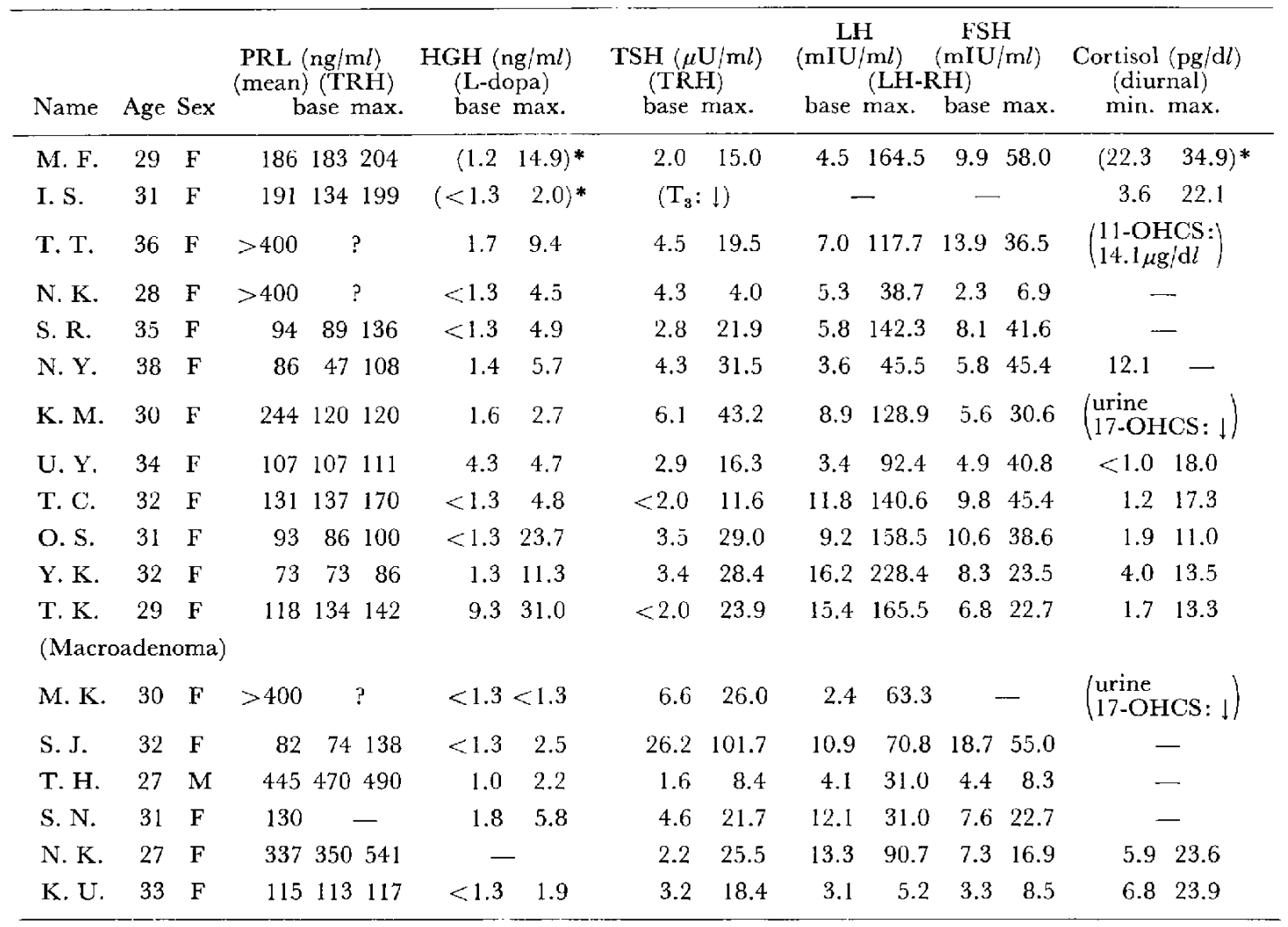

*: insulin tolerance test. 


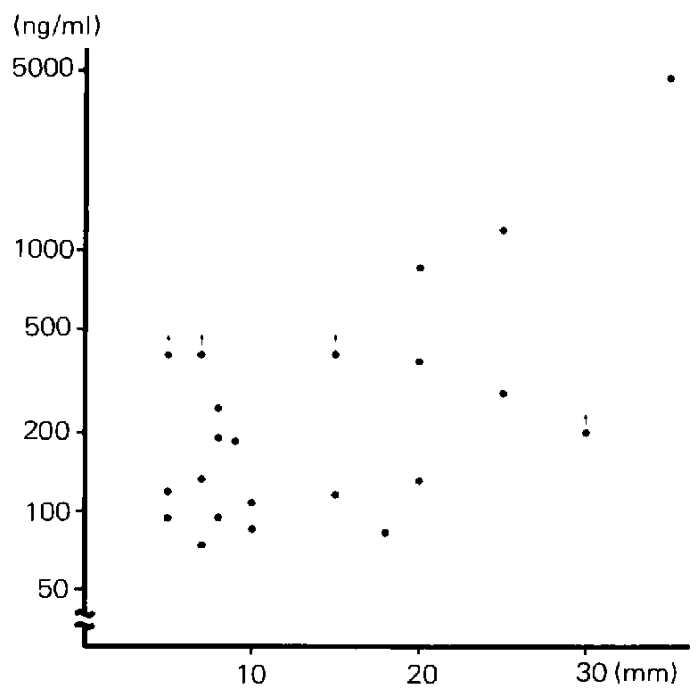

Fig. 4 Mean serum PRL levels and the size of tumors. Macroadenomas ( $>10 \mathrm{~mm}$ ) tend to have higher PRL levels than microadenomas but the PRL level itself can not clcarly differentiate between the two groups ( $f$ indicates out of scale measurement at the level).

して上昇反応（前值の $100 \%$ 以上増量）がみられたに過ぎ ず，macroadenoma では，4例いずれる反応がみら扎な かった.

血清 PRL の日内変動は, microadenoma 05 例, macroadenoma の3 例いずれも睡眠中に有意な上昇がみ られなかった。

L-dopa 試験に括ける正常抑制効果（前值の $50 \%$ 以上 減少) は, microadenoma の 11 例中 9 例に, macroadenoma $の 5$ 例中 4 例にみられ，両者の閒で有意の差はみ られなかった（Fig. 5). Bromocriptine 試験における正 常抑制効果（前值の $50 \%$ 以上減少）は， microadenoma の8例中 5 例に, macroadenoma の2 例中 1 例に欢られ た. L-dopa 試験, Bromocriptine 試験いずれにも反応し ないものが microadenoma のI例にみられた。

\section{(2) HGH 分泌機能}

血清 HGH 基硟值の平均值は microadenoma，macroadenomaいずれも $5 \mathrm{ng} / \mathrm{m} l$ 以下であった. Microadenoma には 2 例の eosinophilic adenoma, 2 例のmixed adenoma が含まれていたがこれらの例でも血清 HGH 值は上昇 していなかった。

L-dopa 試験では, microadenoma 010 例中 6 例が正 常反応（最高值 $5 \mathrm{ng} / \mathrm{m} l$ 以上）を示したが， macroadenomaでは 5 例中 1 例に正常反応がみられたに過ぎない.
(\%)
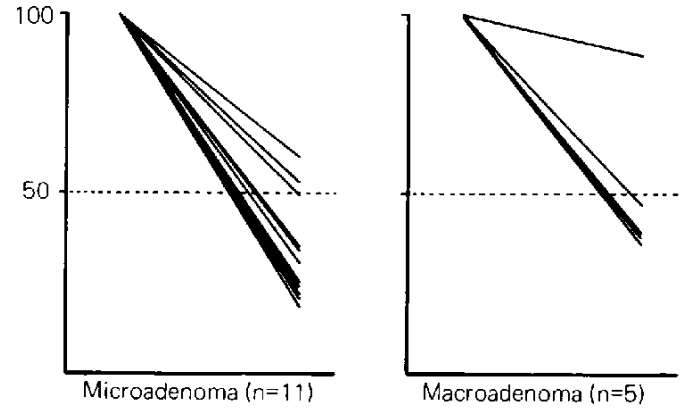

Fig. 5 L-dopa suppression effect on the serum PRL. The baseline PRL per cent after the oral administration of L-dopa (500 $\mathrm{mg}$ ) is shown. There is no definite difference between microadenomas and macroadenomas.

ITTは microadenoma の9例に行われたが，有効な 血糖值の低下（前值の50\%以上）が得られたのは 5 例の みで，このうち4 例に正常反応（最高值 $10 \mathrm{ng} / \mathrm{m} /$ 以上） がみられた. Macroadenoma では 2 例いずれも正常反応 がみられなかった。

血清 $\mathrm{HGH}$ の日内変動で睡服中の上昇が確認されたも のは1例もなかった。しかし，これは採血間隔が長すぎ ることも関係しているかも知れない。

L-dopa 試験, ITT いずれにも反応せす， HGH 分泌 不全し判定さ机たものは, microadenoma では12例中 5 例 $(41.7 \%)$ で, macroadenoma の5 例中 4 例 $(80.0 \%)$ に比し少なかった (Table 2).

\section{(3) TSH 分泌機能}

血清 TSH $の$ 基碟值 (正常值： $2 \sim 10 \mu \mathrm{U} / \mathrm{m} l$ ) に異常 がみられたものは, microadenoma, macroadenoma とも にきかめて少なかった。 TRH 試験では, microadenoma のI1 例中10例㕶正常反応(最高值 $10 \mu \mathrm{U} / \mathrm{m} l$ 以上) を示し， macroadenoma では 6 例中 5 例が正常反心を示した.

血清 $\mathrm{T}_{3}, \mathrm{~T}_{4}$ は microadenoma $の 10$ 例中 1 例に $\mathrm{T}_{3}$ の 低下がみられたのみで， macroadenoma の5 例ではいず 机も正常で市った。

TRH 試験吕行かれなかったものについては, $\mathrm{T}_{9}, \mathrm{~T}_{4}$ 值の結果を考慮し，TSH 分泌不全と判定されたものは， microadenoma で12例中 2 例 $(16.7 \%)$, macroadenoma で6例中 1 例 $(16.7 \%$ ) といずれも少なかった（Table 2).

\section{(4) LH，FSH 分泌機能}

血清 LH 基礎值が正常 $(4.8 \sim 19.0 \mathrm{mIU} / \mathrm{m} l)$ のもの は, microadenoma で 11 例中 8 例, macroadenoma で 6 例中 3 例であった. LH-RH 試験（Fig. 6) で LH 分泌 
Table 2 Preoperative evaluation of endocrinological reserves in 12 cases of PRL-secreting pituitary microadenoma compared with 6 cases of macroadenoma.

\begin{tabular}{|c|c|c|c|c|c|c|}
\hline Name & $\begin{array}{l}\text { PRL } \\
\text { reserve }\end{array}$ & $\begin{array}{l}\text { HGH } \\
\text { reserve }\end{array}$ & $\begin{array}{l}\text { TSH } \\
\text { reserve }\end{array}$ & $\begin{array}{l}\mathrm{LH} \\
\text { reserve }\end{array}$ & $\begin{array}{l}\text { FSH } \\
\text { reserve }\end{array}$ & $\begin{array}{l}\text { ACTH } \\
\text { reserve }\end{array}$ \\
\hline M. F. & $\mathrm{S}$ & $\mathrm{N}$ & $\mathrm{N}$ & $\mathrm{N}$ & $\mathrm{N}$ & $S$ \\
\hline I. S. & $S$ & $\mathrm{~S}$ & $\mathrm{~S}$ & - & - & $\mathrm{N}$ \\
\hline $\mathrm{T} . \mathrm{T}$ & ? & $\mathrm{N}$ & $\mathrm{N}$ & $\mathrm{N}$ & $\mathrm{N}$ & $\mathrm{N}$ \\
\hline N. K. & $?$ & $\mathrm{~S}$ & $\mathrm{~S}$ & $\mathrm{~S}$ & $\mathrm{~S}$ & $\mathrm{~N}$ \\
\hline S. R. & $S$ & $\mathrm{~N}$ & $\mathrm{~N}$ & $\mathrm{~N}$ & $\mathrm{~N}$ & $\mathrm{~N}$ \\
\hline N. Y. & $\mathrm{N}$ & $\mathrm{N}$ & $\mathrm{N}$ & $\mathrm{S}$ & $\mathrm{N}$ & $\mathrm{N}$ \\
\hline K. M. & $\mathrm{S}$ & $\mathrm{S}$ & $\mathrm{N}$ & $\mathrm{N}$ & $\mathrm{N}$ & $\mathrm{S}$ \\
\hline U. Y. & $S$ & $\mathrm{~S}$ & $\mathrm{~N}$ & $\mathrm{~N}$ & $\mathrm{~N}$ & $\mathrm{~N}$ \\
\hline T. C. & $\mathrm{S}$ & $\mathrm{S}$ & $\mathrm{N}$ & $\mathrm{N}$ & $\mathrm{N}$ & $\mathrm{N}$ \\
\hline O. S. & $\mathrm{s}$ & $\mathrm{N}$ & $\mathrm{N}$ & $\mathrm{N}$ & $\mathrm{N}$ & $\mathrm{N}$ \\
\hline Y. K. & $\mathrm{S}$ & $\mathrm{N}$ & $\mathrm{N}$ & $\mathrm{N}$ & $\mathrm{N}$ & $\mathrm{N}$ \\
\hline $\begin{array}{l}\text { T. K. } \\
\text { (Macro }\end{array}$ & $\mathrm{S}$ & $\mathrm{N}$ & $\mathrm{N}$ & $\mathrm{N}$ & $N$ & $\mathrm{~N}$ \\
\hline M. K. & ? & $\mathrm{S}$ & $\mathrm{N}$ & $\mathrm{N}$ & - & $S$ \\
\hline S. J. & $\mathrm{S}$ & $\mathrm{S}$ & $\mathrm{N}$ & $\mathrm{N}$ & $\mathrm{N}$ & $\mathbf{N}$ \\
\hline T. $\mathrm{H}$ & $\mathrm{S}$ & $\mathrm{S}$ & $\mathrm{S}$ & $\mathrm{S}$ & $\mathrm{S}$ & $\mathrm{N}$ \\
\hline S. N. & - & $\mathrm{N}$ & $\mathrm{N}$ & $S$ & $\mathrm{~N}$ & $\mathrm{~N}$ \\
\hline N. K. & S & - & $\mathrm{N}$ & $\mathrm{N}$ & $\mathrm{N}$ & $\mathrm{N}$ \\
\hline K. U. & $\mathrm{s}$ & $\mathrm{S}$ & $\mathrm{N}$ & $\mathrm{S}$ & $\mathrm{S}$ & $\mathrm{N}$ \\
\hline
\end{tabular}

$\mathrm{S}$ : subnormal, $\mathrm{N}$ : normal

不全（正常：最高值 $50 \mathrm{mIU} / \mathrm{m} l$ 以上）と判定されたもの 法, microadenoma で11例中 2 例 $(18.2 \%)$ で, macroadenoma の 6 例中 3 例 $(50.0 \%)$ 飞比し少なかった (Table 2).

血清 FSH 基喽值（正常： $10 \mathrm{mIU} / \mathrm{m} l$ 以下）が上昇し ているものが microadenoma の 11 例中 2 例, macroadenoma の 5 例中 1 例に歿られた. LH-RH 試験（Fig. 6) で $\mathrm{FSH}$ 分化不全 (正常：最高值 $10 \mathrm{mIU} / \mathrm{ml}$ 以上) と判 定されたもの标，microadenoma で11例中 1 例 $(9.1 \%)$ で, macroadenoma $の 5$ 例中 2 例 $(40.0 \%)$ 飞比し少な かった。

\section{(5) $\mathrm{ACTH}$ 分泌機能}

血清 cortisol 值の深夜の最低值と早朝の最高做の比較 から, 正常の日内変動 $(8 \mu \mathrm{g} / \mathrm{d} l$ 以上の差)がmicroadenoma 6 例, macroadenoma 2 例の全例に吅られた。

ITTにより血清ACTH の测定を行ったが, microadenoma, macroadenoma いず扎も有効な低血糖值が得ら れなかった。

血清 cortisol 值の日内変動在主とし, その他, 血清 cortisol, ACTH 基碟值, 血清 11-OHCS, 尿中 17-OH CS，尿中 17-KS の結果を参考にして，ACTH 分泌不 全と判定されをものは，microadenoma で 12 例中 2 例 $(16.7 \%)$, macroadenoma で 6 例中 1 例 $(16.7 \%)$ とい すれれも少なかった（Table 2)。

以上総括すると，PRL 産生脑下垂体 microadenoma では，PRL 起除くと HGH 分泌不全が多い $(41.7 \%)$ が，その他のホルもン分泌不全は少なかった $\{9.1 \sim 18.2$ \%)。こ礼に反し， macroadenoma では，HGH 分泌不全 が同様にもっとも多く $(80.0 \%)$,ついでLH, FSH 分泌 不全が目だつ $(50.0 \%, 40.0 \%)$ が，TSH，ACTH 分 泌不全 $(16.7 \%)$ 㤌 macroadenoma と差を認めなかっ た.

\section{$\mathrm{V}$ 考案}

PRL 産生腷下垂体 microadenoma の報告け近年 增加

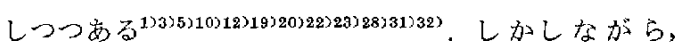
“microadenoma”の定義は必ずしも統一されていない. トルコ鞍単結撮影の所見と手術で確認された腺腫の大き さの雨者を考虑して，Hardy ${ }^{12)}$ は,トルコ鞍の大ささが 正常（トルコ鞍前後径が $16 \mathrm{~mm}$ 以下, 高さが $13 \mathrm{~mm}$ 以 下, 面積が208 $\mathrm{mm}^{2}$ 以下) で, 腺腫の大きさが $3 \sim 10$ $\mathrm{mm} の$ すの定義し, Wiebe et al. ${ }^{311}$ は，トルコ鞍が正 
LH
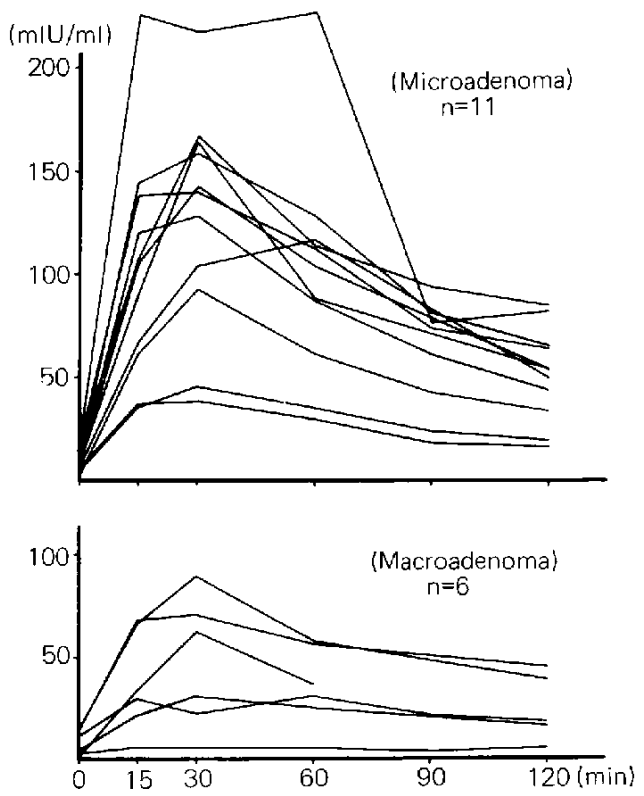

FSH
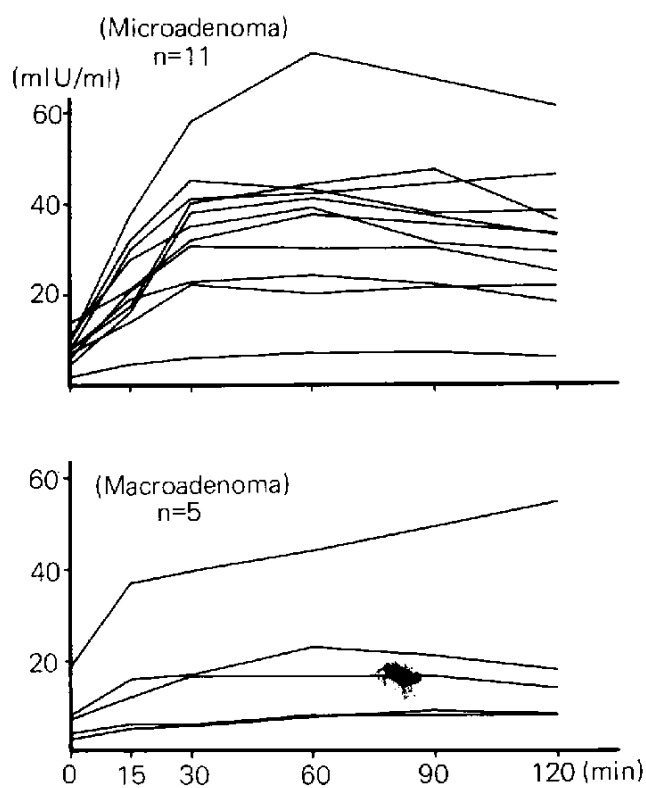

Fig. 6 Serum LH and FSH response to LH-RH. Normal response of serum LH was obtained in 9 out of 11 cases of microadenomas but only 3 out of 6 cases of macroadenomas. Normal response of serum FSH was obtained in 10 out of 11 cases of microadenomas but in 3 out of 5 cases of macroadenomas.

常で, 腺腫の大きさが0.5 1.1 cm のものと定義してい る.腺腫の大きさだけ党問題にして, Wilson \& Dempsy ${ }^{32}$ は3〜9 mm のbのを, Chang et al. ${ }^{5)}$ は10 mm 以下て 鞍外伸展のあるものも含み， Tindall et al. ${ }^{28)}$ 江 $9 \mathrm{~mm}$

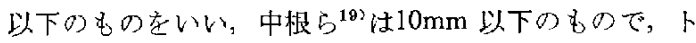
ルコ鞍察積が大きいるのも含んでいる. Robcrtson \& Newton ${ }^{21}$ は，トルコ鞍単純撮影の所見を重視し、トルコ 鞍画積，トルコ鞍容積がともに正常なものをいい，腺腫 は1.5 cm までのものを含んでいる。手術で腺腫の大き さを正確に計测することは必ずしも容易ではないので， 我々注トルコ鞍単䄴撮影で, トルコ鞍面積, 容積が正常 であることを条件として，腺腫の大きさが10 \&のを microadenoma と定義した。

脳下垂体 microadenoma の神経放射線学的診断上, hypocycloidal tomography の側面像に扔けるトルコ鞍底 の限局性の expansion, bulging, blistering あるいは cortical thinning が重要であるといわれている゙1121)801. 我々の例でもをれ確認された。 Microadenoma がCT

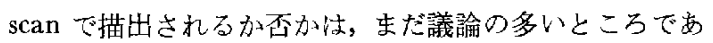
3. Belloni et al. ${ }^{2)}$ は, chromophobe adenoma で contrast enhancement でトルコ鞍内に 結節性の高吸収域
として描出されると報告し，Wolpert et al.33) は，PRL 産生腺腫では 28例中 1 例が enhancement で高吸收域と して描出され，5 例の壞死性腺腫で低伋収域として描 出されたとい5. Syvertsen et al. ${ }^{24}$ は, microadenoma の診断には, 横断像は partial volume averaging のために 判読が困難で, 前頭断像が優れ，PRL 産 生 microadenoma では, enhance された正常脳下垂体の中に低吸収城 として描出されるといら，PRL 生産 microadenoma CT scanによる正確な䛦断は, high resolution CT scanner による今後の検討を待つべきであるら。

PRL 産生腌下”亚体腺腫の診断として，血中 PRL值が

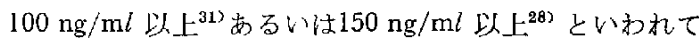
いるが, Friesen \& Hwang ${ }^{10)}$ にると, macroadenoma では200 ng/ml 以上であるが， microadenoma あるい梳 二次的に視床下部䘮侵寸病変の場合に注, $30 \sim 200 \mathrm{ng} / \mathrm{ml}$ のこともあるといら，したがって，血中 PRL 值のみで PRL 産生腷下垂体腺腫と診断することはできない. PRL 座生脳下垂体腺腫の閒でも，Chang et al. ${ }^{52}$ にるる 血中 PRL 值は microadenoma では15 133(72 2) ng/ $\mathrm{m} l$; macroadenoma では $110 \sim 1,500(494 \pm 82) \mathrm{ng} / \mathrm{ml}$ と 後者の方が高いが, Tindall et al. ${ }^{28)}$ によると， micro- 
adenoma では $25 \sim 1,345 \mathrm{ng} / \mathrm{ml}$, macroadenoma では26 $\sim 4,000 \mathrm{ng} / \mathrm{m} l$ と両者の間にあまり差がない，我々の例 では, macroadenoma $は$ microadenoma に比 L血中PRL 高值の例が多いが，PRL 值だけで両者を区別すること はできなかった。

高 PRL 血症と乳汗漏出の関保について, 我々の microadenoma O) 12例中11例飞, macroadenoma $の$ 女性 例 7 例中 5 例飞乳汁涌出がみられたが，血中 PRL 值の 高さと乳汁漏出の発現との間には関連性がみられなかっ た。高 PRL 血症がありながら乳汁漏出のない例15)18 では，その原因として，Malarkey \& Johnson ${ }^{17)}$ は，測 定された PRL の生物学的活性が正常もしくは低下して いるのではないかという。しかし他の多くの考党では， 乳汗漏出をきた寸ためには，他のホルモン（estrogen, progestcrone, corticosteroid, insulin) に上る乳房の淮備 状態が必要で, PRL だけでは乳汁漏出が起こらないとい $5^{637) 10314)}$. Zárate ct al. ${ }^{34)}$ によると，視床下部障害に上 る二次的 PIF 障害の場合活乳汁滿出がみられないとい 5、一方，乳汁漏出がありながら血中 PRL 值が正常の 例も稀にみられる方5113 ので注意を要する。

PRL 産生脳下垂体腺腫と無月経ないし月経不順の関 係をみると，我々の microadenoma $の 12$ 例中11例に無月 経，1例に月経減少がみられた. Hardy ${ }^{12)}$ の20例の乳汁 漏出が双られた腺腫中18例に, Chang ct al. ${ }^{53}$ の高 PRL 血症を示した腺腫28例中27例に無月経，月経滅少がみら れた。高 PRL 血将と無月释との間の機序についてはま だよくわかっていないかが, Boyar et al. ${ }^{32}$ は, microadenoma の場合, LH，FSH の基碳值，LH-RH 比す る反心も正常であることから，腺腫による正常脳下垂体 への圧迫の影響仙考えら机ず，高 PRL 血症そのもの が，周期的な性腺刺激ホルモンの作用索妨げるのではな いかといい, Friesen \& Hwang $^{10\rangle}$ も microadenoma $の$ 場 合, PRL が卵集, 視床下部のいずれか，亦るいは両者 に作用してLH，FSH の正常な周期的分泌を抑制してい るのであちうといっている. Thorner et al. ${ }^{15)} も$ PRLが LH，FSH の合成，分泌を抑えるよりむ，LH，FSHが性 腺作用するの阻止すると考えている。このことは， 我々の microadenoma の例で，LH-RH に対するLH， FSH の反忘が正常な 9 例飞も無月経, 月経娍少がみら れたことからもらなずける。しかし，Quigley et al. ${ }^{20)}$ の例では， microadenoma でも血中 $\mathrm{LH}$ 基礎值が著明に 低下しておう， dopamineの視床下部に扔ける LH-RH に対する抑制作用の充進による LH 分泌不全が無排卵 の原因であると考えている。. Franks et al. ${ }^{2)}$ 恃また，高 PRL 血症の場合, estrogen 産生障害があることを無月
释の原因と考えている。

血中 PRL の TRH に対する反応は，佐藤 ${ }^{22} の$ microadenoma 6 例中 3 例任正常ないし遅姃反応がみらうた 落,これはむしろ例外的で, microadenoma, macroadenoma いずれも反㐫が双られないか，ごく稀にしか反応

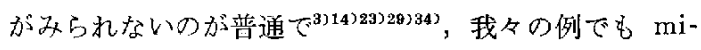
croadcnoma の1例で遅延反応が办られたに過ぎない.

TRH に対する反応がみられない原因は, Kleinberg et al. ${ }^{14)}$ に上ると，(1)腫瘍細胞が最大限に PRL を分泌し， それ以上刺激に反応しないか，(2) TRH に対する受容性 が消失ないし変化したのであるらという。血中 PRLの 日内变動汢, microadenoma ${ }^{3)}$, macroadenoma ${ }^{17)}$ いずれ の場合にも消失するといわ机ている。

血中 PRL 飞対する L-dopa の抑制效果は, 約50 100\%の例に奻られ, microadenoma, macroadenoma $の$ 間で有意な差はみられず317)232312，我々の例です同椂で

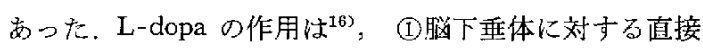
作用と，(2)視床下部のPIF に対する刺激作用が考えら れるので，L-dopa に対する抑制効果の有無から PRL産 生畄下垂体腺腫の成因を論ずることはできない，また，

L-dopa でPRL が抑制されないことを microadenomaの 診断根挟としているWiebe et al. ${ }^{31}$ の考えは正しくな い. Bromocriptine $\sigma$ PRL に対する抑制効果 ら ${ }^{199}$ にる上, microadenoma, macroadcnoma $の$ 全例に みられたといらが，我々の例で忹半数にしかみられなか oた.

血中 HGH $の$ 基礎值 noma いずれも正常籍囲にあるといわれている(115). IT Tに対する反心は，microadenoma で放40５0\%の例に 低下がみられろ と年223 といらが, Wiebe et al. ${ }^{311}$ の例では 4 例小 3 例记, Schaison et al. ${ }^{232}$ の 8 例すべてに正常反 応がみら机，我タの例でも5 例中 4 例飞正常反応がみ られた。一方, macroadenoma では Chang et al. ${ }^{5)}$ によ ると 7 例中 2 例にしか正常反応がみられず, Zárate et al. ${ }^{34)}$ の例では 7 例中 6 例に正常反忘がみられたが，後 者の判定基準が最高值 $5 \mathrm{ng} / \mathrm{m} l$ 以上とい5点が問題であ る.

Microadenoma に招ける血中 HGH のL-dopa に対寸 る反応についての報告は見当らないが，我々の例では， microadenoma では macroadenoma に比し障害される例 が少なく, Malarkey \& Johnson ${ }^{17)}$ の macroadenoma 例でもすべて反応がみられなかった。

血中 TSH の基喽值注 microadenoma, macroadenoma

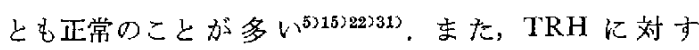
る反忘は microadenoma では活とんど正常のことが多 
く133223，これに対し macroadenoma では $60 \sim 70 \%$ の例 に政常反店がみられるとい5151824)。我々の例では，而 者ともTRHに対する反応の低下がみられたものは少な かった，血中 $\mathrm{T}_{3}, \mathrm{~T}_{4}$ 注 microadcnoma では正常のこと が多いが3(5)22)23)313, Lundberg et al. ${ }^{153} の$ macroadenoma の例では 8 例中 4 例に $\mathrm{T}_{4}$ の低下がみられた。

LH-RH に対方 LH，FSH の反応は，LH の方が障 害されや与いのて，障害の程度老知る上で上り信頼性が 高いといわ礼る゙4)，Microadenoma では血中 LH基礎值 はほ上んよ゙正常で，LH-RH に対する反応す約70\%以上 は正常である゙3)221231311。これに反し，macroadenoma た は基礎值は約半数以上が低下し，LH-RH に対する反応

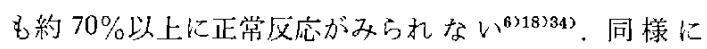
microadenoma だは血中 FSH 基碟值㧍よび LH-RH に 刘与る反応はほぼ正常で3512223331》, macroadenoma では 血中 FSH 基礎倠括よびLH-RH に対する反応の低下が みられる1834)。これらの傾向は我々の例ですみられた。 ただ Chang et al. ${ }^{52} の$ 報告では, macroadenoma でも LH 分泌不全江稀で, FSH 分泌不全もほとルどみられ ないのに反し, microadenoma でも Quigley et al. ${ }^{203}$ の 13例す心゙てに著明な LH 分泌不全がみられた。

ACTH 分泌機能は 血 中 cortisol 值 加らみて microadenoma ではほとんどの例で正常である る 机に反し macroadenoma で注 1/3以下の例に障害され $b^{5 / 141518) 28}$. 我々の例では, microadenoma, macroadenoma いずれも障害される例は少なく両者の間に差は 欢られふった。

\section{V 結 論}

1. PRL 産生譄下垂体 microadenoma 12 例について 神経放射線学的診断, 内分泌学的所見について検討を行 った.

2. 神程放射線学的診断には, hypocycloidal tomography 側面像に㧍けるトルコ鞍底の限局性“"expansion” と “cortical thinning” の所見がもっとも重要であった。

3. 内分泌学的所見として, 血中 PRL の值のみ加ら microadenoma と macroadenoma を区別することはでき なかった。血中 PRLの TRH に対する反応は microadenoma 1 例に崌延反応がみられたに過ぎない.PRL 以外のホルモン分泌機能は, microadenoma では通常も っとも障青されや市いHGH 分泌障圊が多くみられ，そ の他のホルモンについては障害が少なかった。これに反 L, macroadenoma では HGH 分泌障害がより高頻度に みられ，LH，FSH 分泌障害も多くみられたが，TSH， $\mathrm{ACTH}$ 分泌障菁は少なかった.
稿を終るにあたり，腚例を御紹介いたたいた札幌医科 大学座婦人科用中昭一博士に心から感謝します。

\section{文献}

1) Antunes, J. L., Housepinn, E. M., Frantz, A. G., Holub, D. A., Hut, R. M., Carmel, P. W. \& Qufst, D. O.: Prolactin-secreting pituitary tumors. Ann Neurol 2: 148-153, 1977

2) Belloni, G., Baciocco, A., Borrell, P., Sagui, G., DiRocco, C. \& Matra, G.: The value of CT for the diagnosis of pituitary microadenomas. Neuroradiology 15: 179-181, 1978

3) Boyer, R. M., Kapen, S., Weitzmay, E. D. \& Hellman, L.: Pituitary microadenoma and hypcrprolactinemia. A cause of unexplained secondary amenorrhea. $N$ Engl $J$ Med 294: 263-265, 1976

4) Buckman, M. T., Kaminsky, N., Conway, M. \& PEAKe, G.T.: Utility of L-dopa and water loading in evaluation of hyperprolactinemia. $J$ Clin Endocrinal Metab 36: $911-919,1973$

5) Chang, R. J., Keye, W. R., Young, J. R., Jr., Wilson, C. B. \& JAFFe, R. B.: Detection, evaluation and treatment of pituitary microadenomas in patients with galactorrhea and amcnorrhea. Am IJ Obstet Gynecol 128: 356-368, 1977

6) Child, D. F., Nader, S., Mashiter, K., KJeld, M., Banks, L. \& Fraser,T. R.: Prolactin studies in "functionless" pituitary tumours. $B r$ Med I 1 : 604-606, 1975

7) Daugiaday, W. H.: The adenohypophysis. pp 31-79, In Williams, R. H. (ed): "Textbook of Endocrinology', W.B. Saunders Company, Philadelphia, London, Toronto, 1974

8) DiChiro, G. \& Nelson, K. B.: The volume of the sella turcica. Am $J$ Roentgenol 87: 989-1008, 1962

9) Franks, S., Murray, M. A. F., Jequier, A. M., Steele, S. J., Nararro, J. D. N. \& Jacobs, H. S.: Incidence and significance of hyperprolactinemia in women with amenorrhea. Clin Endocrinol 4: 597-607, 1975

10) Friesen, H. \& Hwang, P.: Human prolactin. Ann Rev Med 24: 251-270, 1973

11) Gefhr, R. B., Allen, W. E., Rothman, S. L. G. \& Spencer, D. D.: Pluridirectional tomography in the evaluation of pituitary tumors. $A m$ $J$ Roentgenol 130: 105-109, 1978

12) HARDY, J.: Transsphenoidal surgery of hypersecreting pituitary tumors. pp 179-194, In Kohler, P. O. \& Ross, G. T. (eds): "Diagnosis and Treatment of Fituitary Tumors", Excerpta Medica, Amsterdam, American Elsevier Pub- 
lishing Company, New York, 1973

13) Hwang, P., Guyda, H. \& Friesen, H.; A radioimmunoassay for human prolactin. Proc Nall Acad Sci 68: 1902-1906, 1971

14) Kleinberg, D. L., Noel, G. L. \& Frantz, A. G.: Galactorrhea : a study 235 cases, including 48 with pituitary tumors. $N$ Engl $J$ Med 296: 589-600, 1977

15) Lundberg, P, O., Drettyer, B, Hemmingsson, A., Stenkvist, B. \& Wide, L.: The invasive pituitary adenoma. A prolactin-producing tumor. Arch Neurol 34: 742-749, 1977

16) Malarkey, W. B., Jacobs, L. S. \& Daughaday, W. H.: Levodopa suppression of prolactin in nonpuerperal galactorrhea. $N$ Engl $J$ Med 285: 1160-1 163, 1971

17) Malarkey, W. B. \& Joinson, J. C.: Pituitary tumors and hyperprolactincmia. Arch Intern Med 136: $40-44,1976$

18）松村茂次郎，森信太郎，大田正博，魚住 徽， 滝本 昇, 湻辺 優, 大西利夫, 熊原雄一，宮 井 橴 : Large prolactinoma $\varnothing$ 臨床的検討。神 経外科 19:1107-1113,1979

19）中根藤七，景山直樹，桑山明夫，渡辽正男， 蟹江規雄：ホルモン産生下垂体腺腫に対する経 蝶形骨洞手術。日外会誌 11:1004-1008, 1979

20) Quigley, M. E., Judd, S. J., Gilliand, G. B. \& YEN, S. S. C.: Effects of a dopamine antagonist on the release of gonadotropin and prolactin in norrnal women and women with hyperprolactinemic anovulation. $J$ Clin Endocrinol Metab 48: 718-720, 1979

21) Robertson, W. D. \& Newton, T. H. : Radiologic assessment of rituitary microadenomas. $\mathrm{Am}$ $J$ Roentgenol 131:489-492, 1978

22) 任藤恒治：Hyperprolactincmia と下垂体腫序. ホルモンと臨床 26:67-71, 1978

23) Schaison, G., Nathan, C., L'Hermite, M. \& Gilbert-Dreyfus: Etude de la prolactne et des gonadotrophincs plasmatiques dans les aménorrhées-galactorrhées. Exploration dynamique dans 13 cas. Nouv Presse Méd 4: 644-648, 1975
24) Syvertsen, A., Haughton, V. M., Williams, A. L. \& Cusick, J. F.: The computed tomographic appearance of the normal pituitary gland and pituitary microadenomas. Radiology 133: 385-391, 1979

25）田辺紦䕒，未松克美，传藤 修：下垂体腺腫 診断に叔讨る bone window CT の有用性に関市 る検討. 脳神経 32 :585-592，1980

26）田辺純嘉，传藤 修：Thin-section hypocycloidal tomography $に よ z$ pituitary microadenoma の彭断. 脸外（投稿中）

27) Thorner, M. O., McNeili.y, A. S., Hagan, C. \& Besser, G. M.: Long-term treatment of galactorrhea and hypogonadism with bromocriptine. Br Med J 2: 419-422, 1974

28) Tindale, G. T., Mclanahan, C. S. \& Christy, J. H.: Transsphenoidal micro surgery for pituitary tumors associated with hyperprolactinemia. $J$ Neurosurg 48: 849-860, 1978

29) 魚住 徹, 森信太郎，村松茂次郎：プロ チン産生下垂体腫瘍，ホルモンと臨床 26: 1007 $-1014,1978$

30) Veztna, J. L. \& Sutton, T. J.: Prolactinsecreting pituitary microadenomas, Roentgenologic diagnosis. Am J Roentgenol 120:46-54, 1974

31) Wiebe, R. H., Hammond, C. B. \& Borchert, L. G.: Diagnosis of prolactin-sccreting microadenoma. Am J Obstet Gynecol 126: 993-996, 1976

32) Wilson, C. B. \& Dempsey, L. C.: Transsphenoidal microsurgical removal of 250 pituitary adenomas. $J$ Neurosurg 48: 13-22, 1978

33) Wolpert, S. M., Post, K. D., Biller, B. J. \& Molitch, M. E.: The value of computed tomography in evaluating patients with prolactinomas. Radiology 131: 117-119, 1979

34) Zákate, A., Canales, E. S., Villalobos, H., Soria, J., Jacobs, L. S., Kastin, A. J. \& SChally, A. V.: Pituitary hormonal reserve in patients presenting hyperprolactinemia, intrasellar mass, and amcnorrhca without galactorrhca. $J$ Chin Endocrinol Metab 40; 1034-1037, 1975 